\title{
Primary School Teachers' Opinions on Professional Development (Professional Development Model Proposal) ${ }^{*}$
}

\author{
Eyüp Ekinci ${ }^{1}$, Filiz Evran Acar $^{2}$ \\ ${ }^{1}$ İstanbul, 34295, Turkey. E-mail: ekincieyp@ gmail.com \\ ${ }^{2}$ Faculty of Education, Department of Education Sciences, Düzce University, Düzce, 81620, Turkey \\ Correspondence: Filiz Evran Acar, Faculty of Education, Department of Education Sciences, Düzce University, Düzce, \\ 81620, Turkey. E-mail: filizacar@duzce.edu.tr
}

Received: February 11, 2019

doi:10.11114/jets.v7i4.4039
Accepted: March 7, 2019 Online Published: March 13, 2019

URL: https://doi.org/10.11114/jets.v7i4.4039

\begin{abstract}
The purpose of this study is to provide a model for effective professional development by taking the opinions of the primary school teachers on professional development. Grounded theories and techniques which are qualitative research methods have used in the research. Twenty primary school teachers from a district, Küçükçekmece, Istanbul participated in the study, and the data were collected through interview. To reach the model, firstly, the opinions of the participants about the concept of professional development, the processes of providing professional development and the characteristics of effective professional development were taken. The opinions about the idea of professional development are in three sub-categories: change, experience, and burnout; views on the processes of ensuring professional development are in four sub-categories: physical conditions, technology, academic resource, and training process and opinions on the characteristics of effective professional development are being convenience to the needs, right of choice, appropriate content selection, development strategy, active learning environment, and cooperation. In the light of these results, effective professional development model categories are feeling a need, goal setting, planning, development process, and evaluation respectively and these categories constitute a cycle in itself. It was concluded that there should be support and monitoring activities to ensure coordination between the main categories and teacher(s).
\end{abstract}

Keywords: primary school teacher, professional development, effective professional development model, grounded theory

\section{Introduction}

Developments such as the expectations of the 21 st century's from individuals, international student exams, globalization, speed of access to information and new technologies have led to changes in teacher competencies and the roles expected from them. In line with the changing needs, the need for teachers to acquire new knowledge, skills, and attitudes makes professional development important.

Professional development includes processes of supporting the development of professional knowledge, skills, values, and attitudes. As a result of the development of the teacher's professional behavior; students, school administrators, and families benefit from this. Professional development is a process starting from pre-service and continuing with the first step to teaching and in service. Professional development aims to inform teachers about changing and developing educational approaches. Also, it seeks to provide the necessary knowledge, skills, and behaviors to make them more effective and efficient teachers (Aytaç, 2000). Teachers can use professional development to gain in-depth knowledge about a subject. It can also be used to contribute to their academic or professional expertise (Lieberman, 1995).

The professional development of teachers has begun to gain importance. As such, the minimum qualification period for teachers has started to change. For candidate teachers in most European countries, a master's degree is required (Eurydice \& Eurostat, 2012) because teachers are required to bring their countries into a position that can adapt to the developing and changing world.

\footnotetext{
*This study was produced as Eyüp Ekinci Master's thesis which was carried out under the consultancy of Filiz Evran Acar. In addition it was presented as an oral presentation at the II nd International Eurasian Educational Research Congress (June 8-10, 2015)
} 
Although the teaching profession in Turkey is a profession that legally requires particular expertise, the requirements of professionalization are not be adequately met (Celkan, 1998). Especially in the 1990s, the preference order of the primary school teacher among the university student candidates has lost its value. Generally, the students who cannot place other branches choose the primary school teachers department in order not to be unplaced. As a result of this, it is stated that they do not show enough interest in the lessons and their desire to succeed is low (Oktay, 1991). Only in 1996, it was noted that tens of thousands of young college graduates were appointed as teachers and later they received pedagogical formation lessons for less than two months. Besides, in the 2000s, the appointment of any faculty graduate as primary school teachers caused bloodletting of the profession (Akyüz, 1998). For these reasons, it is thought that primary school teachers should give importance to professional development to increase their professional qualifications. According to the report of OECD TALIS (OECD, 2009), it is stated that the participation of teachers to in-service training activities carried out in Turkey is on the last rank among the teacher participation in other countries. It can be said that service training carried out in Turkey does not provide regular and efficient professional development to the teachers. Due to these negativities, new approaches and insights on in-service training should be developed. It is essential to reveal the perceptions of teachers about effective professional development and professional development processes. Presenting a new professional development model in light of these perceptions and the literature can contribute to teachers.

In this research, it is aimed to get the opinions of primary school teachers about professional development and to present an effective professional development model in line with these opinions. By this primary objective, the following questions are tried to be answered and the results obtained are interpreted:

1. What are the opinions of the teachers about the concept of professional development?

2. What are the opinions of the teachers about the process of professional development?

3. What are the opinions of primary school teachers about the characteristics of effective professional development?

4. What are the features of an competent professional development model?

In this way, it is thought that the data to be obtained at the end of the research will be able to guide the professional development activities which will be carried out.

\section{Method}

\subsection{The Research Model}

In this study, grounded theory and techniques of qualitative research methods are used. Grounded theory is the general methodology which consists of data collected and analyzed by systematically applied methods and used to develop an inductive theory on a specific area (Douglas, 2004). This concept by Glaser and Strauss (Glaser \& Strauss, 2009) points to a sampling approach that requires the collection of data until the fulfillment of the ideas and processes that may be the answer to the research question. Accordingly, the number of participants can vary.

\subsection{Study Group}

When selecting the participants; maximum variation sampling from purposive sampling methods was used to maximize the diversity of the individuals who could be a subject to the problem of research. Maximum sampling aims to try to find out whether there are any common or shared phenomena between the various situations and to reveal the different dimensions of the problem according to this diversity (Yıldırım \& Şimşek, 2011). While selecting the participants, age, seniority, gender, type of institution (public, private), graduation degree (undergraduate and graduate) and socioeconomic status of the school were taken into consideration. Also, the individuals who were thought to be the source of the research were chosen preferably.

The study group of this research consists of 20 primary school teachers working in seven different schools in a district, Küçükçekmece, İstanbul. Eighteen of the teachers were from public schools; two of them were selected from private schools. According to their demographic background, six of them were female, 14 were male, 18 were undergraduate, and two were graduate. The years of experience vary between 5 years and 35 years, and ages between 27 and 55 years. Since grounded theory technique is used, no limit is set when determining the number of participants. Interviews have been continued until the data is thought to start repeating one another (Strauss \& Corbin, 1998).

\subsection{Instruments for Data Collection}

Semi-structured interview questions were used as data collection instrument. The most appropriate data collection instrument for the purpose of the study was considered as interview because the interview is a process of mutual and interactive communication based on the way of asking and answering questions for a severe and predetermined purpose (Strauss \& Corbin, 1998; Yıldırım \& Şimşek, 2011). The interview process is explained below. 
In the preparation of the interview questions, a literature review was made first and then presented to the expert opinion. Some trial interviews were conducted before the actual meetings started. An average of 15-minute an interview was performed with six primary school teachers. It is understood that the interview questions evoke the same meaning in the minds of the participants; Preliminary meetings were continued until the case was clearly stated. After the questions were formed by the grounded theory, the main implementation was started.

\subsection{Data Collection}

Data collection lasted for nine months. The participants were interviewed, in the teachers' room or the meeting rooms and the interviews were recorded with a voice recorder. The meetings were submitted to the participant for approval before being registered with the voice recorder, and they guaranteed about the parts that they do not want are excluded. Reluctant teachers for interviewing despite this assurance were not included in the study.

Data collection took place in three steps. Firstly, semi-structured interview questions were asked to the participant teacher. Afterward, the interview data were analyzed by putting down on paper, and the next interview questions were revised and updated. Finally, the interviews were continued until the data obtained by continuous comparative analysis repeat themselves and fulfillment was achieved. The data received from the meetings were subjected to constant evaluations by consulting to the expert opinion.

Interviews with teachers vary between 15 minutes and 48 minutes and the total recording time is 405 minutes. Their answers range from 505 words to 1748 words and consist of 26208 words in total. Some of the interviews are short, but they do not cause a negative situation. If the participants gave clear answers to the questions they were asked, the meeting was not extended further.

\subsection{Data Analysis}

The data were analyzed by grounded theory in accordance with the qualitative pattern. The analysis of the data was provided in three steps in terms of the open, axial and selective coding process (Strauss \& Corbin, 1998).

The first stage of the open, axial and selective coding process is the transcription of the interviews with the participants. The researcher takes notes about the meetings and conceptualizes them. The concepts obtained after conceptualization are classified under categories and subcategories related to axial coding. These classifications are presented in detail in the findings of the first, second and third sub-problems. In selective coding, the subcategories and categories were re-classified according to their progressive and dimensional characteristics, and the main categories were reached. The professional development model, which is formed with the main categories, is presented in the fourth sub-problem.

\subsection{Validity}

The data collection process, the analysis of data and the consistency of the data interpretation process are among the factors that increase the validity of the research. The reflectivity of the research results and their applicability to other situations increases the validity (Ekiz, 2009). It can only be achieved by a detailed explanation of all stages of the research (Yıldırım \& Şimşek, 2011). In this section, the following practices have been carried out to increase the validity of the study.

Interviews with teachers were recorded with the help of a voice recorder and the data obtained as a result of the meetings were written directly. The data were presented to the participant. If they did not fully explain the idea they wanted to express, they were requested to correct them and misstated, or unwanted parts were excluded from the study. With this way, the facts and cases that were not clear could be described more clearly. Continuous comparative analyses have been performed to make the findings meaningful and consistent.

Participants were informed about interviews with the previous participants and the findings. The participants were asked whether the results from other participants were realistic or not and it was found to be realistic. In order to be able to confirm that the findings reflect the meaning desired to be expressed clearly; direct quotations are included in the findings section. While analyzing the data of the research; another expert, besides the researchers, coded and the independent analyses were combined, and the common coding was taken into consideration. Spreading the interviews throughout nine months provided some advantages in preventing possible misconceptions and mistakes caused by researchers.

\subsection{Reliability}

Reliability of research depends on several factors such as whether the findings reflect the truth-if so, to what extent it reveals, and the study conducted at different times and places yield the same results (Ekiz, 2009). As the agreement of the evaluation of two or more independent observers on the same object or individual increases, the reliability of the study increases (Balc1, 2010). To increase the reliability of the study, a branch teacher with a master's degree in education programs and teaching was asked to code the interviews. The consistency value between the two analyses 
conducted by the researcher and the field teacher was taken as the reliability coefficient..Presenting one-third of the encodings made during the analysis process to an expert opinion is thought to increase reliability. For this purpose, the number of agreements and disagreements of the coding of 7 of 20 participants were determined, and the coding reliability was calculated, and it was 0,90 . In qualitative studies, the desired level of reliability is ensured in cases where the compliance between expert and researcher assessments is $90 \%$ and above (Miles and Huberman, 1994). In this context, it can be said that the research is reliable.

The written forms of interviews were read several times in detail. To prevent the prejudices that may arise from the researcher in the interpretation of the research data, the related literature has been reviewed, and the opinion of an expert has been consulted. The placement of the obtained codes in the category and main categories was also subjected to the same processes. During the interviews, the voice recordings which were taken with the permission of the teachers and the documents that the written forms of the records were kept to be subjected to an examination process.

\section{Results}

In the research, the question is "What should be the effective professional development model for the class teachers?" focused on. In this context, it was tried to be reached the main purpose by taking opinions of the professional teachers about the professional development concept, the processes of providing professional development and the characteristics of effective professional development (Figure 1).

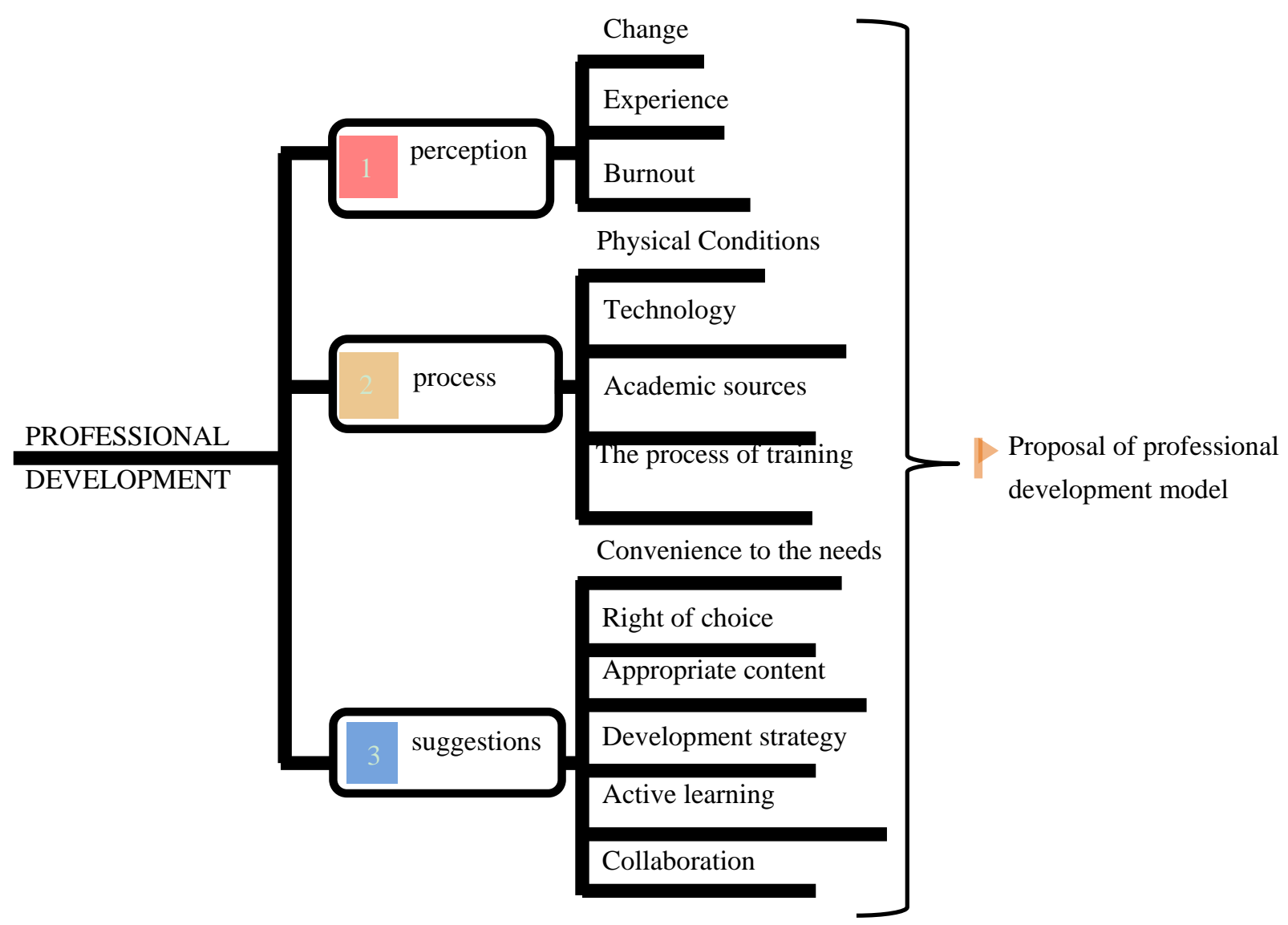

Figure 1. Primary School Teachers' Opinions on Professional Development

\subsection{Primary School Teachers' Perceptions on Professional Development}

When teachers' perceptions of professional development are examined, it is seen that they focus on three concepts: change, experience, and burnout. Under the concept of change, they talked about the need to improve themselves, to keep up with the change, to get rid of monotony and increase their experience by mentioning the change of the generations, the loss of functionality of the information with time, the technological developments and the change of programs. A teacher says that: "You need improvement so that you keep up with the times. If you fall behind the time, you cannot get anywhere. The times are changing; the possibilities are changing. You must also develop and change in a positive way that you can keep up with the time. We cannot solve many problems if we fall behind the time" (T7). This 
statement of a teacher puts forward the necessity of keeping up with change. They also stated that professional development, in relation to the concept of experience, provides teachers knowledge, skills, and experience, but teachers also mentioned their experiences gained through trial and error. Teachers' perceptions of burnout are also remarkable when it comes to the concept of professional development. In this context, teachers may be reluctant, unhappy, tired, unexcited, and resentful towards professional development. They attributed the reasons for this to the lack of change in professional development, to the fatigue of the profession, to be extremely safe, to a dull professional life, to financial problems, not to be respected and to obligatory professional development activities. Some of the teachers stated that such excuses are meaningless and they cannot provide any benefit and if these excuses are not be put away, development cannot be achieved.

\subsection{The Process of Professional Development of Primary School Teachers}

When the opinions of the teachers about the professional development process are examined, it is seen that they talk about physical conditions, technology, academic resources, and training process.

Teachers stated that in relation to physical conditions, transportation to the place where professional development activities were done was a problem, they encountered hardware inadequacy in the education environment, and they felt uncomfortable with the training that arranged in crowded, closed and inadequate halls.

Teachers stated that they used technology in the process of acquiring professional development and the tools they used most were computer and internet. They indicated that they used interactive training sites and forums to renew themselves, to follow new developments or to get a solution for a problem they encountered.

Teachers consider universities and printed sources as academic sources. In this context, they mentioned about the training provided by the academicians and benefits of workshops, they also stated that instructions should be given by the experts in the field of education and they achieved professional development through graduate education. Teachers can also make use of printed sources to improve their professional development by reading books and following the educational articles of newspapers. Developing these resources and providing facilities for teachers to access these resources can be useful in terms of professional development.

With regard to the process of professional development training, teachers said that non-practical information was provided. They pointed out that the subjects did not attract attention, obliging the education made them feel uncomfortable, and the training was perfunctory. They also talked about the imposition of issues, the training of non-experts, the inefficiency of direct instruction method, the short-term interlocutory instructions, and the unplanned and inadequate training. According to these explanations, teachers stated that they were dissatisfied with the educations and they were inefficient.

\subsection{Primary School Teachers'Suggestions for Effective Professional Development}

When the suggestions of the primary school teachers about the effective professional development were examined, the concepts of convenience to the needs, right of choice, appropriate content, development strategy, active learning environment, and cooperation were reached.

Teachers recommended that a professional development activity can respond to the needs, reflect life, be able to be used in class, solve class problems and meet parents' expectations. Also, teachers recommended that they should be given the right of choose their professional development activities which are suitable for individual differences, and they should plan their development. They stated that teachers did not pay necessary attention to the training which was not given the right to prefer, they were tired of seeing the training with similar content, and they could be willing to attend the training that organized according to their preferences. The teachers' opinions regarding this situation are as follows: "If you force the teacher to attend the training, the receptors will not be open because the teacher thinks about a different development point. If the options offered to the teacher are limited, the teacher closes the receptors if they do not want any of them" (T1).

Another important factor determining the effectiveness of the professional development program was the content. The participants stated that the content of the professional development activities prepared for them was given; theoretically, they did not reach the application level, they were given as a shallow, repetition of the known things and they did not arouse any curiosity.

Teachers have expressed different characteristics in terms of development strategy. In this context, teachers state that self-control, reflective thinking, idealism, self-criticism, reasoning, being open to communication and empathy are the features of effective professional development. For example, a teacher emphasized the importance of empathy by looking at someone else's or students' eyes by saying this: "The teacher inevitably improves himself/herself as he/she gets experience. If we can look from a child's point of view, we can learn something with time" (T11). It can be said that developing some development strategies can benefit the teachers in providing effective professional development 
because the professional development efforts that act with intrinsic motivators without any external pressure and demand can be more successful and productive.

Teachers also argue that professional development should be in an active learning. In this context, they demand a professional development process with active participation, hands-on, micro-teaching demonstrations, case studies, one-to-one, face-to-face communication with small groups, sharing experiences, and school-based activities.

Another suggestion regarding the professional development of teachers is collaboration. All participants stated that they acquired a significant part of their professional development thanks to their colleagues. In this context, sharing of experiences of the colleagues, exchange of ideas and suggestions on a subject, learning from experienced teachers, and group collaborations have been mentioned. It is frequently expressed that cooperation is essential for effective professional development. In this way, teachers stated that they had easier access to information and that time wasted in trial and error processes was prevented.

As a result, data related to the idea of professional development are combined in three sub-categories: change, experience, and burnout. Thus, while teachers perceive the concept of professional development as a means of getting knowledge, skills and experience, they also feel reluctant, unexcited and burnout towards professional development. When the opinions on how professional development is provided are analyzed, teachers mentioned about physical conditions, use of technology, the academic resources they used and the problems they experienced in the process of education. Suggestions about the characteristics of effective professional development include being appropriate to the needs of the teacher, giving the right to choose, content selection according to the needs and new developments, personal development strategies, active teaching environment, and cooperation.

\subsection{Proposal of Professional Development Model for Primary School Teachers}

These categories, which were obtained from the first three problems of the study, were rearranged with selective coding to form a model (Figure 2). Based on the grounded theory techniques, an explanatory theory has been put forward by the data obtained (Strauss \& Corbin, 1998).

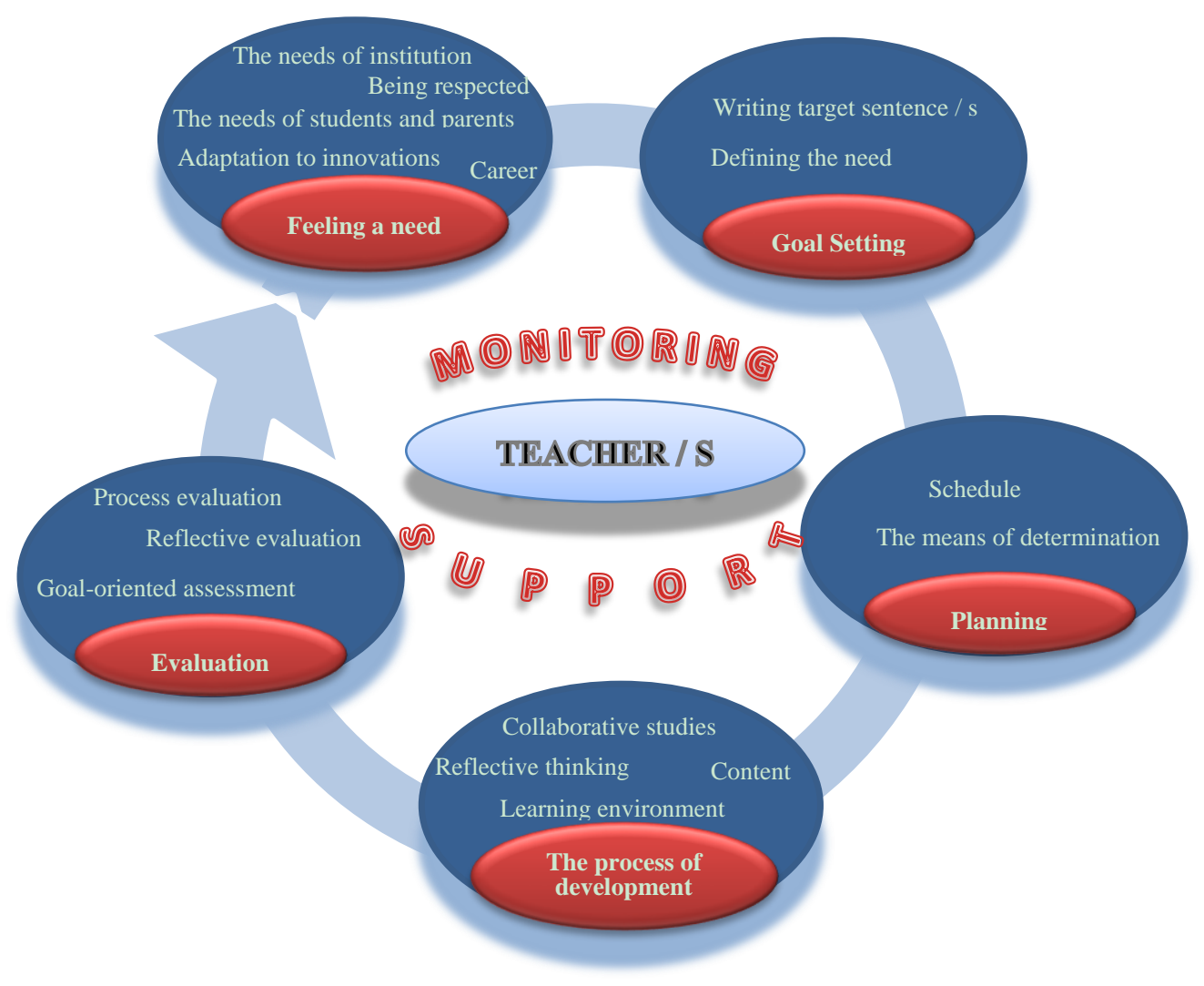

Figure 2. Proposal of Professional Development Model for Primary School Teachers

There are five stages of an effective professional development model. These steps continue as a loop. The model develops and renews itself. The stages are respectively; need, goal setting, planning, the process of development and evaluation. There are support and monitoring steps to ensure coordination between the teacher(s) and the stages at the 
center of the cycle and to ensure the harmony within the stages themselves.

Feeling a need: According to the results of the research, it is possible to say that the first step of effective professional development is the need. It is possible that a teacher who does not feel the need for improvement or has no awareness of evolution will never be in the professional development process or even benefit from this process effectively. In this research, teachers need development due to respect, career-making, specialization in the profession, adaptation to innovation, and meeting the needs of students, parents, and institutions.

Teachers want to be respected by students, parents and the community. They believe that the necessary condition of respect can only be fulfilled by being competent in the teaching profession. Teachers are also thought to have a desire to advance in their careers. By doing a master's degree, they want to move up in their career ladder with the titles of expert teacher and headteacher. They can see professional development as an instrument in the process of fulfilling these requests. Teachers are trying to meet these expectations and requirements by making a career.

Teachers stated that the education they had at the university was not sufficient alone to perform a right teaching profession alone. However, it can be thought that teachers' experience is not enough to specialize in the profession of teaching and teachers consider acquiring professional development as a necessity to specialize in the job. It is thought that the age, technology, curricula, teaching methods and techniques and the continuous change of generation bring about the necessity of adapting to innovations for teachers. Teachers stated that the knowledge acquired in the pre-service period was old in the face of innovations and it should be updated. It is thought that there is a strong relationship between adaptation to change and the need for professional development.

It is thought that meeting the needs of students, parents and institutions are essential for teachers in the professional development process. Some situations such as changes in the era, technological innovations, renewal of educational programs, the need for new teaching methods and techniques, change of generation, etc. situations may affect the expectations of students and parents about education. Therefore, teachers who want to meet the continually differentiating and dynamically structured expectations of students and parents need professional development. The institutions may have some expectations from teachers to reach the goals. These expectations are thought to cause the teachers to feel the need for professional development. However, the attitude of the institution towards the teachers may affect the teachers' feeling about this need because the teachers who participated in the research stated that their professional development initiatives did not find support within the organization and when they were left alone and not adopted by the managers/teachers, they could give up their professional development tendencies. In this case, it is vital for the institution to support professional development initiatives and encourage all teachers to do so.

Goal Setting: Determining the targets that will meet the needs of the teacher who enters the process of obtaining professional development may increase the likelihood of reaching success because attempts to acquire professional development whose objectives are not clearly defined may not be efficient. Teachers who feel the need for professional development may need to identify this need and write target sentences to address it. It is essential for the teachers to make a clear definition of the situations in which they want to improve themselves. Individual behavior of teachers in determining the target may not be sufficient in the completion of an effective professional development process. For this reason, student, parent, colleagues' and managers opinions in the organization can be taken into consideration before the definitions are made. The teacher can make a self-evaluation by expressing the need for professional development. Writing target sentences about the need through the definitions set forth undoubtedly may contribute to the success of professional development. The goal set for the need will guide the planning which is the next phase.

Planning: The planning phase is the process of clearly identifying what, when and how to do in the professional development process. Planning what needs to be done can increase the effectiveness and traceability of professional development work. It is essential to identify the means of determination in the planning phase clearly. While planning, the institution or the teacher's evaluation of the opportunities will contribute to achieving the goal. When the professional development activities are carried out, it is necessary to meet the logistic needs such as meeting room, transportation, etc., the possibility of the support of the expert, mentor, academic staff from universities, etc. can be determined and included in the development process.

For effective planning, it is essential to take into consideration the current conditions and to make a process/schedule. Determining how long the development process will take when to start and end, as well as deciding which persons, institutions or organizations will be contacted, may increase the likelihood of professional development to be successful. It is essential to align the qualified plans with the other development practices of the school. The school management or related team can support teachers in integrating the activities. Also, for the teachers in the school, this team can prepare a process/schedule for the professional development process whose goals are determined. This process/schedule indicates when the professional development activities will begin and end. At this stage, it is also possible to plan which support will be given to the teachers at points such as time, place, transportation, paid leave, as well as expert assistance and financial 
assistance. The teacher's possible to feel comfortable in his/her development process and to focus on professional development can be increased by preparing the planning process well.

The process of development: The development process is related to the ways in which teachers use and how to use them in their professional development. In this process, content, learning environment, collaborative studies and reflective thinking processes can affect the efficiency of the professional development process.

In the process of professional development, it is crucial to making the content appropriate to the student, parent and institution's needs, exciting and instructive, and giving the teacher the right and freedom to choose the content can be motivating.

Learning environments in the development process can be formal and informal. Informal learning environments, it is essential to benefit from people who are experts in their fields, can contribute to the development of teachers, are interested in the implementation environment, and are aware of the lives and classes of teachers. Teachers complain about the inefficiency of the training based on the theoretical knowledge which is not oriented towards the implementation, especially the education of the non-competent people.

Besides, the factors such as the interaction of trainers, being open to communication, having a fluent narrative, creating active learning environments, giving interactivel question-answer activities and giving exciting examples about the implementation are among the other important factors that increase the effectiveness of the learning environment in professional development. When the physical aspects of learning environments are considered, it is vital that the settings are organized in a way that is not crowded, well equipped, physical conditions are convenient, and transportation is easy.

Informal learning environments can be in the form of learning alone, learning by one-on-one coaching, learning within groups of teachers, interactive training and cooperative learning. Cooperative activities are especially important in professional development. In this process, the teacher can consult with other teachers who are in their professional development process, share professional experience, get colleague advice and share resources. Collaborative works such as community sharing and visits to colleagues at other schools can be organized. It can be said that colleagues get more rapid and effective professional development with the help of cooperative work.

One of the most important factors that increase the efficiency of professional development processes is to operate reflective thinking processes. Reflective thinking requires the use of comprehension, memorization, apllication of knowledge and ability to solve problems related to the new situations, to explain, to synthesize, to generalize and to develop hypotheses (Üstünoğlu, 2006). Since it helps teachers to find solutions to the problems and to make healthy decisions, it can be considered as an essential talent or cognitive behavior that teachers should develop (Dewey, 1997). During the professional development process, the teacher may not be able to receive support services from the mentor, colleagues and so on. In such cases, the teacher should be able to guide himself/herself through reasoning and reflective thinking.

Evaluation: It may be necessary to assess at the end of the development process to measure to what extent the goals meet the requirements needed at the beginning. These assessments can be goal-oriented assessment, process evaluation, and reflective evaluation. Evaluation at the end of the training process can give some insights to demonstrate how successfully the professional development process has been achieved.

With goal-oriented assessment, it can be assessed that to what extent the objectives set at the outset were achieved. To goal-oriented assessment, opinions of other stakeholders such as students, parents, and colleagues can be used along with the views of teachers. In this evaluation, the reflections of development on the classroom, student outcomes, and changes in teacher behavior can be evaluated.

Through the process evaluation, all components from the beginning to the end of the professional development process can be evaluated. Process evaluation can provide clues for the improvement of effective professional development and can be useful to make up deficiencies and correct the errors. The process evaluation is vital to understand whether the need is well defined, how appropriate the development process goals are determined, whether the planning process has been done well, the development process is efficient, and the evaluation has been done correctly. Process evaluation can guide other professional development activities.

Reflective thinking is a process of knowledge-based and logical decision-making on educational issues and then evaluating the results of these decisions (Taggart \& Wilson, 2005). In the process of professional development, raising awareness and the teacher's internalization of the improvement is essential. The teacher should be able to develop self-control skills with reflective thinking and evaluate him/herself at every stage of professional development. These self-control skills can provide the teacher with the ability to supervise himself/herself in the process of professional development or to guide him/herself in the next professional development activity. In this way, the professional 
development cycle can gain a self-structuring and developing a feature.

Support and Monitoring: Support and monitoring act as a bridge between the teachers who are at the center of the professional development model and the professional development process. In addition to this task, it is a crucial element of the development process.

It is vital that there are some support and monitoring activities for stages of planning of need, goal setting, planning, development process, and evaluation to progress successfully. The teacher can provide support activities during his / her professional development period. These aids may include all kinds of financial and emotional support. The monitoring activities can be defined as all of the work done to manage, plan, organize and develop the professional development process. A common feature of both support and monitoring activities is that they represent a person, people or an organization apart from a teacher. These people could be experts, academicians, mentors, coaches, colleagues, etc. As well as institutions contained within the Ministry of Education, there may also be non-governmental organizations (NGO). These NGOs can be associations and foundations.

It is essential to make the teacher not to feel alone. When he/she feels insufficient, he/she should be supported. Providing support and monitoring services to guide the teacher in each of the stages can increase efficiency. It is believed that getting expert assistance means that the teacher, who is in the process of professional development, receives guidance support from an experienced and competent teacher. Teachers may need people who will provide guidance and information resources to support the professional development process.

With the guidance of the colleague, teachers can observe the educational practices of each other. It can be useful to discuss the observed situations with each other, to share their thoughts and to give mutual feedback on the effectiveness of their practices (Bell \& Mladenovic, 2008). Teachers can be coaches of each other by facilitating each other and making easier their learning (Downey, 2001). Teachers can make mutual evaluations which are in the focus of the instructional analysis and consist of observation, feedback, and analysis process by observing each other's lectures (Glatthorn, 1987). Also, experienced teachers can facilitate the instructional development of less experienced teachers through "mentoring, assisting, making suggestions" (Sullivan \& Glanz, 2000).

The teacher may need financial support during the development process. Through legal and institutional supports, some convenience can be provided to the teacher who has difficulty in carrying out the professional development process together with the educational activities. For example; support can be provided through facilitating activities such as planning the course schedules according to the needs of the teacher, giving paid/unpaid leave to the teacher, increasing the teacher's salary to encourage professional development, and meeting the expenses of transportation and accommodation.

Providing social support to the teacher during the professional development process can increase the efficiency since creating the professional development awareness, internalization of professional development and adopting professional development may increase the probability of the process to success. If teachers, who are in the professional development process, know that their initiatives are welcomed by students, teachers, parents, and institutions, their motivation can increase. Some improvements in the personal rights of the teachers who develop themselves can lead to a positive change in the perspective of the teacher towards professional development. Emotional support can be given by expert aids, mentors, colleague cooperation. Social support can be provided through activities such as respecting, caring, giving leadership roles, giving support in every condition.

Support and monitoring activities can allow us to have a general opinion about the needs of teachers because gathering the development processes in a single center may make it possible for another teacher not to repeat the mistakes and to share the successful implementation processes with other teachers.

\section{Discussion and Conclusion}

Teachers of contemporary society should have the ability to adopt continuous learning as a principle, to be sophisticated and democratic, to overcome problems, to solve issues and to think critically, to convert their class into active learning environment (Kuran, 2002). However, teachers may not be able to meet the reflections of all kinds of developments on education with the education they received before the service (Bilir, 2004). Teachers should continuously renew themselves; in short, they need to gain a professional teacher identity. Obtaaining a professional teacher identity can only be possible with a competent professional development. In this research, five themes have been put forward for effective professional development. These themes continue as a cycle, develop and renew themselves. The themes are feeling a need, goal setting, planning, development process, and evaluation respectively. There is support and monitoring steps to ensure the coordination between the teacher(s) and the themes at the center of the cycle and to ensure the harmony within the stages themselves.

To know for what reasons teachers are involved in professional development may give clues for effective professional 
development. For this reason, teachers should feel the need for professional development first. This need may arise from the causes such as being respected, career, specialization in the profession, adaptation to innovation, and the ability to meet the needs of students and parents. According to these results, teachers may feel the need for professional development due to internal motivation. Palermo and Thomson's (Palermo \& Thomson, 2018) research also revealed that teachers' motivation for professional development is primarily related to internal causes. Accordingly, a significant majority of teachers are motivated to participate in professional development to improve students' performance and to increase their success.

Teachers need to define the need before starting an effective professional development process. First of all, the need should be clearly defined, and the target sentences appropriate to this definition should be written. The individual behavior of teachers in determining the target may not be enough to complete an effective professional development process. It is also important to consider the needs of the institution, for when teachers' development is provided with institutional development, the effect on the learners is thought to be more beneficial.

In the process of professional development, it should be clearly defined how professional development will be done, which tasks will be carried out and when they will be carried out and who will complete which tasks and in which position he/she will complete them. Podol (Podol, 1962) defined planning as: "To specify and determine what to do, how to do it, when to take action and who will take over this responsibility."

The teacher's working environment and its facilities should be evaluated while planning professional development. It is possible that the professional development planned beyond the current conditions will not reach its goal. However, the planned professional development considering the circumstances conditions may not be as productive as desired. An competent professional development process can be designed when facilities are determined and acted with an appropriate strategy.

For an effective professional development process, a suitable content should be prepared, and the information should be up-to-date, interesting, useful and ideal for new developments. It is also vital to ensure that teachers are volunteered for professional development. In his/her research, Güneş (Güneş, 2006) concluded that teachers were reluctant to professional development for reasons such as obligation and imposition of the subject.

Teachers' requests should be taken into consideration while determining the place and time of professional development activities (Avşar, 2006; Büyükcan, 2008; Çifci, 2008; Güneş, 2006; Șener, 2009; Ülker, 2009; Ulus, 2009). Furthermore, Büyükcan (Büyükcan, 2008) found that teachers had difficulties in the seminars because of the unfavorable working environment, the lack of materials and proper planning of the seminar studies. Collaboration among colleagues can be ensured to increase the academic success of students and to realize the development goals of the institution. When teachers come together, they can meet their professional development needs more quickly and easily by finding unique solutions to the problems they face (National Staff Development Council, 2009). Teachers can consult experts in their profession for effective professional development. They can improve themselves by asking questions about education or the problems they experience in the classroom to the experts.

The active use of reflective thinking in the professional development process can accelerate the teacher's development. $\mathrm{He} / \mathrm{she}$ can also produce ideas when there is no counseling service. Reflective thinking requires the use of skills such as comprehensive learning rather than memorizing, using knowledge and solving problems related to new situations, explaining, synthesizing, generalizing and developing hypotheses (Üstünoğlu, 2006).

In order to understand whether the professional development process is useful or not, some evaluation activities can be carried out. The central element that increases the quality of the education process is an evaluation. It is an inseparable part of education (Akpinar \& Ergin, 2006). Evaluations can be made in the form of goal-oriented assessment, process evaluation, and reflective assessment. At the target setting stage, it can be evaluated to what extent the determined targets are completed. A holistic assessment of the professional development process as a cycle can be made. Some issues such as determining in whichever stages mistakes are done, which practices are more efficient, and what can be done to improve them can be evaluated. Teachers should be able to think effectively and make decisions by questioning their experiences systematically based on research and by considering the educational environments and conditions (Pollard, 2002). Assessing all aspects of the professional development process can be a facilitator for further professional development processes.

Social, economic and expert supports should be provided to teachers for healthy and regular progress in the effective professional development process. Teachers should be monitored at every moment of professional development. Social support is a factor that positively influences teachers' social identities. With social support, teachers can be protected against the adverse effects they may face in the process of professional development (Kozakl1, 2006). Social support can be provided to the teacher who is involved in professional development, through activities such as respecting, caring, giving leadership roles, continuing to provide support in all circumstances. Also, teachers may feel encouraged 
if they know that these initiatives are welcomed by students, teachers, parents and institutions. Some improvements in the personal rights of the teachers who develop themselves can lead to a positive change in the perspective of the teacher towards professional development.

As a result, this model can contribute to support the development process of primary school teachers and to train qualified teachers. These stages can be taken into consideration while planning teacher training processes.

\section{References}

Akpinar, E., \& Ergin, Ö. (2006). Evaluation of science teachers' exam questions. Milli Eğitim Dergisi, 35(172), 7, 225-234.

Akyüz, H. (1998). Öğretmen Eğitimi Konusunda Bir Öneri [A Proposal for Teacher Education]. Milli Eğitim Dergisi, (137), 34-36.

Avşar, P. (2011). Physical education teacher's evaluation of in-service training programme. Milli Eğitim Dergisi, 40(191), 230-242.

Aytaç, T. (2000). Hizmet içi eğitim kavramı ve uygulamada karşılaşılan sorunlar. [Concept of in-service training and problems encountered in practice] Milli Eğitim Dergisi, (147), 66-69.

Balc1, A. (2010). Sosyal bilimlerde araştırma [Research in social sciences]. Ankara: Pegem Akademi.

Bell, A., \& Mladenovic, R. (2008). The benefits of peer observation of teaching for tutor development. Higher Education, 55(6), 735-752. https://doi.org/10.1007/s10734-007-9093-1

Bilir, M. (2004). İlköğretim öğretmenlerinin hizmet içi eğitimi. [In-service training of elementary teachers] Çağdaş Eğitim Dergisi, (308), 27-33.

Büyükcan, Y. (2008). Effectiveness of in-service training seminars for teachers in primary schools. (Unpublished master's thesis). University of Hacettepe, Institute of Social Sciences, Ankara.

Celkan, H. Y. (1998). Öğretmen yetiştirme modeline yeni bir boyut [A new dimension for teacher training model]. Milli Ĕ̈itim Dergisi, (137), 30-31.

Çifci, S. C. (2008). The determining of the in-service training needs according to the constructivist program of the elemantary education first level (Unpublished master's thesis). Universtiy of Selçuk, Institute of Social Sciences , Konya.

Dewey, J. (1997). Experience and education. New York, NY, US: Simon and Schuster.

Douglas, D. (2004). Grounded Theory and the "And" in Entrepreneurship Research. Electronic Journal of Business Research Methods, 2(2), 59-68.

Downey, M. (2001). Effective coaching: Lessons from the coaches' coach. London, UK: Texere.

Ekiz, D. (2009). Eğitimde araştırma yöntem ve metodlarına giriş [Introduction to research methods and methods in education](1st ed.). Ankara, Turkey: Anı Yayınc1lik.

Eurydice, \& Eurostat. (2012). Key data on education in Europe, 2012. Brussels: Eurydice. Retrieved from https://publications.europa.eu/en/publication-detail/-/publication/9e2d1009-d3bd-4d00-9feb-74cce4d5e990/langua ge-en

Glaser, B. G., \& Strauss, A. L. (2009). The discovery of grounded theory: strategies for qualitative research (4. paperback printing). New Brunswick: Aldine.

Glatthorn, A. A. (1987). Cooperative professional development: Facilitating the growth of the special education teacher and the classroom teacher. Remedial and Special Education, 11(3), 29-34. https://doi.org/10.1177/074193259001100308

Güneş, M. (2006). The reasons for the primary school teachers' willingness or unwillingness to participate in inservice training programmes (sample of Mamak). (Unpublished master's thesis). University of Hacettepe, Institute of Social Sciences , Ankara

Kozakl1, H. (2006). The Relation between social support and loneliness as perceived by the undergraduates who accommodate at the dormitories and their families.(Unpublished master's thesis). University of Mersin, Institute of Social Sciences , Mersin.

Kuran, K. (2002). Öğretmenlik mesleği (niteliği ve özellikleri), [Teaching profession (nature and characteristics)]. In A. Türkoğlu (Ed.), Öğretmenlik Mesleğine Giriş. [Introduction to Teaching Profession] Ankara: Mikro Yayınları.

Lieberman, A. (1995). The Work of Restructuring Schools: Building from the Ground Up. In A. Lieberman (Ed.), The 
work of restructuring schools: Building from the ground up. New York, NY, US: Teachers College Press.

Miles, B. M., \& Huberman, A. M. (1994). Qualitative Data analysis: : an expanded sourcebook (2nd ed.). London: Sage.

National Staff Development Council. (2009). NSDC definition of professional development. Retrieved January 30, 2019, from http://www.dpi.state.nc.us/docs/profdev/resources/definition.pdf

OECD (Ed.). (2009). Creating effective teaching and learning environments: first results from TALIS. Paris, France: OECD Publications.

Oktay, A. (1991). Öğretmenlik Mesleği ve Öğretmenin Nitelikleri, [Teaching profession and qualifications of teacher]. Marmara Üniversitesi, Atatürk Eğitim Fakültesi, Eğitim Bilimleri Dergisi, 3(3), 187-193.

Palermo, C., \& Thomson, M. M. (2018). Large-scale assessment as professional development: teachers' motivations, ability beliefs, and values. Teacher Development, 1-21. https://doi.org/10.1080/13664530.2018.1536612

Podol, R. (1962). Sevk ve idarenin esaslar1, [The principles of referral and administration]. TODAIEE Yayınları.

Pollard, A. (2002). Readings for Reflective Teaching (illustrated edition edition). reprinted: Continuum International Publishing Group Ltd.

Şener, M. M. (2009). Of the class teacher training service levels influence of motivation. University of Marmara, Institue of Education Sciences, İstanbul.

Strauss, A., \& Corbin, J. (1998). Basics of qualitative research: Second edition: Techniques and procedures for developing grounded theory (2nd edition). Thousand Oaks, CA: SAGE Publications, Inc.

Sullivan, S., \& Glanz, J. (2000). Alternative approaches to supervision: Cases from the field. Journal of Curriculum and Supervision, 15(3), 212-235.

Taggart, G. L., \& Wilson, A. P. (2005). Promoting Reflective Thinking in Teachers: 50 Action Strategies (2nd edition). Thousand Oaks, Calif: Corwin.

Ülker, A. (2009). Thoughts of classroom teachers about in-service-training (Sample of Konya/Karapinar district) (Unpublished master's thesis). University of Selçuk, Institute of Social Sciences, Konya.

Ulus, O. (2009). According to teachers' views the assessment of in-service educational programmes. Yayınlanmış Yüksek Lisans Tezi (Unpublished master's thesis). University of Gazi, Institute of Education Sciences, Ankara..

Üstünoğlu, E. (2006). Üst düzey düşünme becerilerini geliştirmede bilişsel soruların rolü [The role of cognitive questions in developing higher order thinking skills] Çağdaş Eğitim Dergisi, 331, 17-24.

Yıldırım, A., \& Şimşek, H. (2011). Sosyal bilimlerde nitel araştırma yöntemleri [Qualitative research methods in the social sciences]. Ankara: Seçkin Yayıncılık.

\section{Copyrights}

Copyright for this article is retained by the author(s), with first publication rights granted to the journal.

This is an open-access article distributed under the terms and conditions of the Creative Commons Attribution license which permits unrestricted use, distribution, and reproduction in any medium, provided the original work is properly cited. 